\title{
O SISTEMA NACIONAL DE EDUCAÇÃO E O ENSINO RELIGIOSO NAS ESCOLAS PÚBLICAS
}

\author{
LuIZ ANTôNio CunHA*
}

\begin{abstract}
RESUMO: A criação do Sistema Nacional de Educação no Brasil tem sido justificada por diversos elementos, entre os quais não aparece a laicidade da educação pública. Para o autor, tal omissão expressa a insuficiente compreensão do Estado republicano e de suas políticas, em especial as políticas educacionais. Esse conveniente (conivente?) silêncio propicia a situação atual da disciplina Ensino Religioso nas escolas públicas, marcada pela anomia jurídica e pela folia pedagógica. Ambas as "patologias" prosperam no aparato educacional brasileiro, fragmentado em múltiplos sistemas, o que abre espaço para a luta pela hegemonia religiosa no campo educacional, privando a escola pública de uma condição essencial da prática republicana - a liberdade de pensamento e de crença, uma e outra propiciadas pela laicidade do Estado.
\end{abstract}

Palavras-chave: Laicidade. Escola pública. Políticas educacionais. Educação brasileira.

\section{The National System of Education and Religious education IN PUBLIC SCHOOLS}

\begin{abstract}
The creation of the National System of Education in Brazil has been justified by several factors, but not by the secularity of public education. For the author, such omission expresses insufficient understanding of the republican State and its policies, especially educational policies. This convenient (complicit?) silence favors the current status of religious education in public schools, marked by legal anomie and pedagogical folly. Both "pathologies" thrive in the Brazilian educational apparatus fragmented into multiple systems, paving the way for the struggle for religious hegemony in the educational field, depriving the public school of an essential condition of the Republican practice - freedom of thought and belief, both due to the secular State.
\end{abstract}

Key words: Secularism. Public school. Educational policies. Brazilian education.

\footnotetext{
* Conferência proferida no IV Seminário de Educação Brasileira (SEB), promovido pelo Centro de Estudos Educação e Sociedade (Cedes), em Campinas (SP), de 20 a 22 de fevereiro de 2013.

** Faculdade de Educação da Universidade Federal do Rio de Janeiro (UFRJ). Rio de Janeiro (RJ) - Brasil. Contato com o autor: <lacunha90@gmail.com>
} 


\section{Le Système National D'Education et L'EnSEignement Reli- GIEUX DANS LES ÉCOLES PUBLIQUES}

RÉSUMÉ: La création du Système National d'Education au Brésil a été justifiée par plusieurs facteurs, entre lesquels il ne figure pas la laïcité de l'enseignement public. Pour l'auteur, telle omission ne démontre pas assez de compréhension de l'Etat républicain et de ses politiques, notamment les politiques éducatives. Ce silence convenable (complice?) favorise la situation de l'éducation religieuse dans les écoles publiques, marquée par l'anomie juridique et la folie pédagogique. Toutes les deux "patologies" prospèrent dans l'appareil éducatif brésilien fragmenté dans de multiples systèmes, ouvrant l'espace à la lutte pour l'hégémonie religieuse dans le domaine éducatif, en privant l'école publique d'une condition essentielle de la pratique politique républicaine - c'est à dire la liberté de pensée et de croyance, l'une et l'autre propiciées par la laïcité de l’Etat.

Mots-clés: Laïcité. Ecole publique. Politiques éducatives. Education brésilienne.

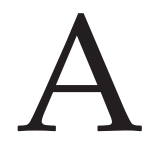

criação do Sistema Nacional de Educação tem sido justificada por diversos elementos, inclusive a autonomização do campo educacional, pelo menos no que diz respeito às interferências do campo político. A inversão das relações de poder entre o Ministério da Educação e o Conselho Nacional de Educação é um desses elementos. Outro é o fim da fúria legisferante de parlamentares federais, estaduais e municipais sobre matéria curricular. ${ }^{1}$ Mas as interferências do campo religioso sobre o campo educacional têm sido esquecidas ou nem ao menos levadas em conta. É sobre essa questão que pretendo convidar à reflexão, quando se trata de um vindouro Sistema Nacional de Educação.

Não adianta fazer de conta que o problema da laicidade não existe. Ele está nas ruas, nas eleições, na saúde pública, nas telas de TV e até nas delegacias de polícia. Não tenho dúvida de que estamos, no Brasil, em plena segunda onda laica. A primeira foi nas últimas três décadas do Império, quando o que havia de melhor nas elites intelectuais e políticas lutou contra a simbiose política-religião para que se instituísse o casamento civil, o registro civil de nascimentos e de óbitos, o direito de votar e de ser eleito para os não católicos, a plena liberdade de culto, a secularização dos cemitérios públicos e a supressão de conteúdos religiosos das escolas públicas - a separação entre o Estado e a Igreja Católica, enfim. Todas essas demandas foram alcançadas com o regime republicano, inclusive o fim do ensino religioso nas escolas públicas, embora por pouco tempo. Naquela época havia um componente externo para a demanda de laicidade do Estado: o favorecimento da imigração branca e cristã, mas protestante, para substituir a força de trabalho negra e pagã.

A segunda onda laica difere da primeira pela maior amplitude e pela origem das demandas, pois as motivações e os agentes são agora internos ao país. Mais do que isso, além de lideranças políticas e intelectuais, cresce a sustentação em movimentos 
sociais. Essa segunda onda laica nasceu nos estertores da ditadura militar, quando da aprovação da emenda constitucional que, em 1977, suprimiu da legislação a indissolubilidade do casamento. Contra o clero católico ameaçando os parlamentares de excomunhão, mas com amplo apoio popular, inclusive dos fiéis, o casamento podia, então, ser reconstituído, com novos parceiros, sem que fosse necessário "casar no Uruguai", artifício somente acessível aos mais abonados.

Quando me refiro a uma segunda onda laica, preciso qualificar esse processo. Ele é contínuo em alguns campos, intermitente em outros, apresenta avanços e recuos em outros ainda. Nos direitos sexuais e reprodutivos, a legislação e as políticas governamentais apresentam avanços consideráveis e contínuos, ao passo que na educação pública tem sofrido recuos importantes.

O Estado laico é aquele que tem sua legitimidade radicada na soberania popular. Ele não só dispensa a legitimidade conferida pelas instituições religiosas como é imparcial em matéria de religião. O Estado laico respeita todas as crenças, religiosas e antirreligiosas, desde que não atentem contra a ordem pública. Ele não apoia nem dificulta a difusão das ideias religiosas nem das ideias que consideram a religião fruto da alienação individual e/ou social. Respeita, igualmente, os direitos individuais de liberdade de consciência e de crença, de expressão e de culto.

Conceito correlato, que os anglo-saxões e os weberianos literais insistem em subsumir àquele, é o de secularização. Laico concerne ao Estado, ao passo que secular concerne à cultura. Distinguir ambos os processos é da maior relevância teórica e prática. Senão, como entender que Estados laicos existem em sociedades de intensas práticas religiosas, e são justamente os garantidores da liberdade de crença? A Índia e os Estados Unidos são exemplos expressivos. Essa distinção permite compreender, também, a existência de Estados confessionais em sociedades altamente secularizadas, como a Grã-Bretanha e a Noruega, esta até recentemente. Distinguir laicidade do Estado da secularização da cultura é também útil para desmontar uma afirmação falsa mas muito comum, proferida com ares de silogismo. Diz-se que o Estado é laico, mas o povo é religioso, deixando implícita a conclusão pretendida: portanto, a presença da religião nas escolas públicas é legítima.

Distinguidos ambos os processos, fique claro que a laicidade do Estado é um pré-requisito político da liberdade de crença e suas manifestações. Crentes de todas e quaisquer religiões, agnósticos e ateus só têm a ganhar com o Estado laico. Têm a temer os que pretendem o exercício da dominação dentro do campo religioso e, conquistada esta, a imposição, por intermédio do Estado, de suas crenças e práticas, inclusive proibições, a toda a sociedade. Estão nesse caso os saudosos do padroado e os arrivistas, que gostariam de gozar dos privilégios que os veteranos da simbiose Estado-Igreja desfrutaram. 


\section{Campo religioso em mudança}

O campo religioso passa por rápidas e profundas mudanças. Até 1980, o declínio da proporção de adeptos do catolicismo foi pequeno mas contínuo. Desde então, cresceu a velocidade da redução do contingente católico, ao passo que se elevou o número de evangélicos, principalmente dos pentecostais, já que os das denominações tradicionais também tiveram seu efetivo encolhido. Os adeptos das religiões afro-brasileiras diminuíram em proveito das confissões evangélicas, algumas delas fornecendo-lhes até mesmo pastores e bispos.

Em números redondos, os adeptos do catolicismo passaram de 93\% em 1960 para $65 \%$ em 2010. Correlativamente a esse decréscimo, os adeptos de denominações evangélicas subiram de $4 \%$ para $22 \%$ no mesmo período. Ainda mais rápido foi o crescimento no longo prazo dos que se declararam "sem religião", de 0,5\% em 1960 para $8 \%$ cinco décadas depois.

Apesar da dificuldade de previsão segura nessa matéria, há quem projete um empate entre o número de católicos e de evangélicos no Brasil, na próxima década, se for mantida a tendência de redução daqueles e de crescimento destes. No estado do Rio de Janeiro, a maioria da população já não se declara católica. No Censo de 2010, os católicos fluminenses somaram $46 \%$ da população e os evangélicos, $29 \%$. A proporção dos declarantes "sem religião" foi de $16 \%$, o dobro da média nacional, o que sugere que a perda de fiéis da Igreja Católica não seja totalmente para as igrejas evangélicas ou de alguma outra religião institucionalizada.

Além dos contingentes de fiéis, o campo religioso mudou muito no espaço ocupado. Até os anos de 1980, todas as religiões ocupavam apenas seu espaço próprio, isto é, templos, centros, terreiros e sinagogas, exceto a Igreja Católica, que promovia procissões e romarias, além de congressos eucarísticos, reunindo multidões nas praças públicas. Desde então, as igrejas evangélicas passaram a ocupar, também, espaços públicos como praças e estádios para cultos de massa, assim como outra dimensão do espaço público, a mídia eletrônica. Emissoras de rádio e televisão, de difusão aberta e via cabo, foram arrendadas ou adquiridas por igrejas evangélicas, para manterem seus fiéis "ligados" na pregação e no entretenimento que os reforcem na fé ou os desviem das alternativas concorrentes ou pagãs.

Um afluente mercado de produtos religiosos prospera, com livros e discos sendo editados em grande quantidade, profissionalizando milhares de pessoas na sua produção e distribuição. Pastores cantores mobilizam massas de fãs/fiéis para o mercado fonográfico e os eventos de multidões.

Esse processo de profunda e acelerada mudança no campo religioso aponta para duas situações ameaçadoras da posição dominante que a Igreja Católica deteve 
em toda a história do país: de um lado, o crescimento das igrejas evangélicas; de outro, o aumento ainda mais rápido dos "sem religião". Reativamente, os dirigentes católicos decidiram investir para recuperar o espaço perdido ou para evitar perda maior. Para isso, adotaram diversos caminhos. Entre eles estão a incorporação das práticas evangélicas dos grandes espetáculos, a ênfase nas prédicas carismáticas, a revalorização dos milagres, o recurso aos padres cantores, redes de TV e, finalmente, mas não secundariamente, a efetivação do Ensino Religioso nas escolas públicas.

\section{Anomia jurídica}

Vejamos o que a legislação manda fazer ou deixa fazer.

Depois de obrigatório no Império e vedado nas primeiras décadas da República, o Ensino Religioso nas escolas públicas é um carma constitucional desde 1934. A Constituição de 1988 reeditou os termos gerais de suas quatro antecessoras, com a seguinte determinação: O Ensino Religioso, de matrícula facultativa, constituirá disciplina dos horários normais das escolas públicas de ensino fundamental.

No ano seguinte ao da promulgação da Carta Magna, cada unidade da Federação promoveu a elaboração de sua própria Constituição. Em 14 estados, os grupos confessionais conseguiram a extensão do Ensino Religioso para as escolas públicas de educação infantil e/ou de nível médio; três estados foram além e estabeleceram a exigência de habilitação própria para os professores dessa disciplina. Depois disso, a legislação estadual ordinária virou terreno fértil para a projeção das devoções de deputados e vereadores, mais despachantes de suas próprias crenças religiosas do que representantes do povo. Aos devotos juntaram-se, no voto de aprovação, os temerosos das ameaças de retaliação política por parte dos grupos confessionais.

Em alguns sistemas estaduais os professores são selecionados no interior do próprio quadro de docentes, noutros a responsabilidade da escolha (indicação ou credenciamento) é alienada em proveito das instituições religiosas interessadas. Prevalece a norma de que os professores sejam do quadro do magistério e portadores de licenciatura, mas, a partir daí, são grandes as diferenças entre os sistemas estaduais. Há os que aceitam quaisquer licenciados, sem a exigência de formação específica; os que limitam o acesso a essa disciplina para os licenciados em Filosofia, História e Ciências Sociais; os que exigem professores com formação adicional ministrada por entidades religiosas ou pelas Secretarias de Educação; e os que especificam a licenciatura em Ciências da Religião, Ensino Religioso e, até mesmo, Teologia, sem faltar os que indicam a possibilidade de aproveitamento de egressos de seminários católicos, com a ressalva de que diplomas equivalentes serão aceitos. 
A Lei de Diretrizes e Bases da Educação Nacional não tinha como evitar a existência do Ensino Religioso nas escolas públicas de Ensino Fundamental, já que a Constituição determinara sua oferta no horário. O deputado Octavio Eliseo Alves de Brito, de assumidas posições laicas, preferiu contornar o problema, não mencionando essa disciplina em seu projeto pioneiro. Já o projeto substitutivo do deputado Jorge Hage procurou transferir seus encargos financeiros e didáticos para as instituições religiosas interessadas.

A pressão contrária do clero católico foi muito grande, secundada por alguma pressão evangélica. O alvo era justamente a posição da disciplina e de seus docentes. Exigia-se que o Ensino Religioso fosse colocado no mesmo plano das disciplinas essenciais do currículo e viesse a receber o mesmo tratamento dispensado às demais. Neste sentido, houve propostas que listavam o Ensino Religioso em seguida às disciplinas abrangidas pela concepção da "educação básica e unitária, indispensável à cidadania plena e à unidade nacional", formulação inicial do substitutivo Jorge Hage. Além da Língua Portuguesa, da Matemática, das Ciências Físicas, Naturais, Sociais e Humanas, a LDB deveria acrescentar o Ensino Religioso. E mais, que os docentes fossem professores, com formação específica e remuneração, como os seus colegas daquelas disciplinas. ${ }^{2}$

Essa demanda eclesiástica foi parcialmente eficaz. Sua maior vitória foi a inserção da modalidade interconfessional do Ensino Religioso, ao lado da confessional. Dessa forma, foram contemplados tanto os partidários do enfrentamento ostensivo entre as distintas confissões, no interior do campo educacional, quanto os adeptos da luta pela hegemonia, dissimuladamente, para o que a modalidade interconfessional era a mais apropriada.

No curto prazo, a grande derrota dos grupos eclesiásticos de pressão foi no que dizia respeito ao uso dos recursos públicos no Ensino Religioso. Depois de um entra-e-sai, no trajeto da Câmara para o Senado e de novo para a Câmara, a cláusula restritiva permaneceu na segunda LDB, como, aliás, esteve na primeira. Posteriormente, aquela como esta tiveram suprimida tal interdição. O Ensino Religioso tampouco foi alçado ao nível das demais disciplinas. No meu entender, mas, também, dos deputados que participaram da produção da segunda LDB, esta não inseriu o Ensino Religioso no currículo - entendido no sentido estrito. Inseriu essa disciplina apenas no tempo (e no espaço, evidentemente) da escola pública de Ensino Fundamental. Assim entendido, programar o Ensino Religioso no horário significa oferecê-lo em momento acessível aos alunos interessados - que eles não tenham de voltar à escola à noite se estudam de manhã, por exemplo; nem aos domingos ou feriados, quando a escola não tem horário normal de funcionamento.

O caráter facultativo do Ensino Religioso, determinado pela Constituição, foi diluído no texto final da LDB. O primeiro substitutivo Jorge Hage não só reconhecia 
a existência dos alunos fora do Ensino Religioso como, além disso e principalmente, determinava que lhes fossem asseguradas "atividades alternativas". No texto final prevaleceu o silêncio sobre tais atividades, o que propiciou a obrigatoriedade de fato dessa disciplina, malgrado o caráter facultativo, de direito.

Logo após a sanção da LDB pelo presidente Fernando Henrique Cardoso e suscitada sua reforma por ele próprio, o Conselho Nacional de Educação manifestou-se sobre o artigo 33 dessa lei. O Parecer n. 5/97, do Conselho Pleno, foi incisivo contra a remuneração dos professores do Ensino Religioso. O texto elaborado por João Antônio Cabral de Monlevade, da Câmara de Educação Básica, e José Arthur Giannotti, da Câmara de Educação Superior, concluiu que, mesmo sem proibição explícita na LDB, não poderia haver ônus para os cofres públicos em decorrência do oferecimento facultativo do Ensino Religioso nas escolas públicas.

Três razões foram apresentadas pelos conselheiros para justificar essa conclusão. Primeiro, o pagamento de professores do Ensino Religioso violaria o artigo 19 da Constituição, que veda a subvenção a cultos religiosos e a igrejas. Segundo, se esse pagamento fosse feito, haveria tratamento desigual do Estado com relação às diversas instituições religiosas, já que a subvenção (a remuneração dos docentes) seria desproporcional à demanda. Os próprios conselheiros exemplificaram: um ou dois alunos de uma religião demandariam o mesmo gasto do Estado do que 30 ou 40, já que a lei garante a opção dos discentes e/ou seus pais/responsáveis. Terceiro, caso o Ensino Religioso fosse ministrado a alunos de dezenas de denominações diferentes, haveria gasto com essa disciplina mais elevado que o destinado às disciplinas obrigatórias, com maior carga horária.

Monlevade e Giannotti finalizaram sua brilhante argumentação manifestando a crença de que estimulavam, com essas ideias, o respeito à Lei, assim como o exercício da liberdade, da democracia e da cidadania. Seu parecer foi aprovado pelo plenário do CNE, em 11 de março de 1997, mas o ministro da Educação, Paulo Renato Souza, reteve o documento no gabinete. Defensor que era do pagamento pelo Estado dos professores do Ensino Religioso, ele esperou a reforma da LDB, que tramitava no Congresso, e somente homologou e publicou o parecer três meses depois da aprovação pelo conselho, justamente na véspera da sessão em que foi aprovada a primeira mudança da lei maior da Educação. Focalizemos essa reforma.

Às vésperas da visita do papa João Paulo II ao Brasil, o ministro da Educação enviou projeto de lei ao Congresso, que o aprovara, mudando o artigo 33 da LDB. Substitutivo redigido por deputado padre católico, juntou dois projetos de autoria de deputados governistas, convergentes ao do MEC, tudo isso gerando a Lei n. 9.475, de 22 de julho de 1997, aprovada em regime de urgência. Embora continuasse de matrícula facultativa nas escolas públicas, o Ensino Religioso foi declarado integrante da formação básica do cidadão. Levada a sério a nova redação da LDB, os pais que não quiserem matricular seus filhos na disciplina Ensino Religioso, faculdade 
garantida pela Constituição, terão de assumir a responsabilidade por sua educação parcial, insuficiente, defeituosa ou falha. Ademais dessa ameaça implícita, foi suprimida a restrição ao emprego de recursos públicos para cobrir os custos do Ensino Religioso nas escolas públicas. Essa omissão abriu caminho para a negociação, em cada unidade da Federação, entre as organizações religiosas e os governos estaduais e municipais para o financiamento de seus agentes no ensino público, inclusive a realização de concursos específicos para o magistério dessa disciplina.

Foi o silêncio mais eloquente que já ouvi!

O silêncio foi logo quebrado pelo Conselho Nacional de Educação que, na Resolução CNE/CEB n. 2/1998, promoveu o Ensino Religioso a área de conhecimento, rebatizada de Educação Religiosa, uma redenominação bem significativa. O Parecer CNE/ CEB n. 2/1998, que propôs aquela resolução, trouxe uma formulação que é uma pérola lógica: "A Educação Religiosa, nos termos da lei, é uma disciplina obrigatória de matrícula facultativa no sistema público". Cumpre indagar: se nenhum aluno a quiser, como pode ser ela uma disciplina obrigatória? A situação é ainda mais esdrúxula, pois, no ano anterior, havia sido aprovado o Parecer CNE/CEB n. 12, determinando que o tempo despendido com o Ensino Religioso não poderia ser computado para a totalização da duração mínima do Ensino Fundamental. Disciplina obrigatória ou área de conhecimento obrigatória, mas que não computa carga horária? ${ }^{3}$

A Resolução CEB n. 7/2010, do mesmo conselho, ao fixar as Diretrizes Curriculares Nacionais para o Ensino Fundamental de Nove Anos, baixou um pouco a pretensão identitária dos promotores da presença religiosa nas escolas públicas: aquela disciplina deixou de ser Educação para voltar a ser Ensino. Todavia, permaneceu com o mesmo status de área de conhecimento, listada depois de Linguagens, Matemática, Ciências da Natureza e Ciências Humanas. O que os grupos religiosos de pressão não conseguiram no Congresso, o conselho lhes deu.

Aí está um tema importante para se pesquisar: mais uma vez o órgão colegiado máximo da educação brasileira muda a lei, se não na letra, pelo menos no conteúdo. Em 1981, o CFE reinterpretou a Lei n. 5.692/71, o maior fracasso do regime autoritário em matéria de política educacional, e a alterou totalmente, descartando a profissionalização universal e compulsória no ensino de $2^{\underline{0}}$ grau. A lei é boa, mas foi mal interpretada, diziam os conselheiros. Dessa vez, o Conselho Nacional de Educação promoveu esse apêndice curricular, o Ensino Religioso, a área de conhecimento, com o mesmo status do que é consensual no Ensino Fundamental. Aliás, o que quer dizer área de conhecimento? Gostaria de ouvir os curriculistas a respeito, antes de ceder à tentação de pensar que este termo não passa de um artifício taxinômico para entronizar o Ensino Religioso no currículo das escolas públicas, ao arrepio do espírito da LDB, não perceptível na letra da lei, mas visível no processo de sua produção. 
Além do faturamento na legislação federal e da fértil colheita estadual e municipal (pareceres e resoluções de conselho incluídas), houve um lance mais ousado do alto clero católico. Sua estratégia para a recuperação do espaço perdido, mediante a estratégia do confronto, culminou na concordata. Tirando proveito amplo dos laços estreitos com altos dignatários da república, ele conseguiu que fosse celebrado um acordo entre o governo brasileiro e o Vaticano/Santa Sé. Antes de prosseguir, vamos precisar o significado desses termos.

Situação única nos campos político e religioso, em todo o mundo, ao Vaticano, instituição política, corresponde, simbioticamente, a Santa Sé, instituição religiosa que exerce a direção mundial da Igreja Católica. Concordata é o nome que se dá a um tratado firmado entre o Vaticano/Santa Sé e qualquer outro Estado, que confere privilégios para essa instituição religiosa operar no território do país em questão. Em geral, são estabelecidas condições especiais de atuação nas instituições estatais (escolas, hospitais, prisões, Forças Armadas), acesso aos meios de comunicação de massa, isenções tributárias, recebimento de recursos financeiros públicos, etc.

Em prosseguimento a gestões iniciadas durante a visita do papa Bento XVI ao Brasil, em maio de 2007, foi firmado um acordo (concordata) entre o Brasil e o Vaticano/ Santa Sé, em novembro de 2008, pelo ministro brasileiro das Relações Exteriores, Celso Amorim, e o secretário de Estado do papa, cardeal Bertone. Em 27 de agosto de 2009, o acordo foi homologado pela Câmara dos Deputados, mediante decreto legislativo, o qual, depois de tramitação rapidíssima, foi aprovado pelo Senado. Às vésperas do carnaval de 2010, o presidente Lula assinou o Decreto n. 7.107, promulgando a concordata Brasil-Vaticano/Santa Sé, que passou a fazer parte do repertório legal brasileiro.

Tornou-se realidade o que jamais acontecera, nem durante o Império, quando o catolicismo era religião oficial. O que parecia impossível desde que, em 1891, o regime republicano extinguira o padroado imperial, sucedeu em 2009: a direção mundial da Igreja Católica logrou que o Estado brasileiro firmasse com ela um tratado que lhe garante privilégios especiais, em termos políticos, fiscais, trabalhistas, educacionais e outros, em total desrespeito aos dispositivos constitucionais.

O artigo 11 da concordata contraria, essencialmente, o artigo 33 do texto reformado da LDB, o qual determina que o conteúdo da disciplina Ensino Religioso seja estabelecido pelos sistemas de ensino (especificamente pelos respectivos Conselhos de Educação), depois de ouvidas entidades civis constituídas pelas diversas confissões religiosas. Assim, pode não haver "Ensino Religioso católico", nem de confissão específica alguma. Se esse conteúdo for de caráter histórico, sociológico ou antropológico, como querem certas correntes de opinião, ou um extrato das doutrinas religiosas conveniadas, o resultado dependerá das correlações de forças políticas em tais entidades civis. 
Manifestações contra o projeto de concordata partiram de diversos setores, inclusive religiosos, mas prevaleceu o apoio, por dois vetores. Um deles foi resultado do rolo compressor político do governo federal; o outro foi o aceno aos evangélicos de projeto de lei simétrico à concordata. Com o álibi de regulamentar dispositivos constitucionais que tratam da liberdade de crença e do livre exercício dos cultos religiosos, esse projeto consistiu numa adaptação forçada do texto da concordata, no qual a expressão "Igreja Católica" foi substituída por "instituições religiosas". A exceção foi o artigo referente ao Ensino Religioso, que previu, implicitamente, o interconfessionalismo.

Em suma, no mesmo dia, a Câmara dos Deputados bateu no cravo e na ferradura: aprovou a concordata, beneficiando a Igreja Católica, e o acordão, beneficiando as igrejas evangélicas. Como se nada houvesse de absurdo, aprovou duas orientações para o Ensino Religioso nas escolas públicas: pela primeira, ele deve ser confessional católico e de "outras religiões"; pela última, implicitamente interconfessional.

O acordão revelou-se um engodo dotado de grande eficácia. Diferentemente da concordata, que tramitou como decreto legislativo, a lei que daria às igrejas evangélicas o mesmo status político da Igreja Católica não passou de projeto de lei, e foi abandonado às vicissitudes da tramitação ordinária. Encontra-se esquecido no Senado há três anos...

Montado esse quadro jurídico-político, a luta contra a concordata continua, na sociedade e no âmbito do próprio Estado.

A Procuradoria-Geral da República apresentou ao Supremo Tribunal Federal uma Ação Direta de Inconstitucionalidade (ADI), visando tanto à concordata BrasilVaticano quanto à LDB. ${ }^{4} \mathrm{~A}$ ação pedia que o STF interpretasse ambos os textos legais com base na Constituição, de modo a vedar o Ensino Religioso nas escolas públicas em caráter confessional ou interconfessional, bem como proibir o ingresso no quadro do magistério público de professores representantes de confissões religiosas.

A argumentação da ADI partiu do princípio de que a LDB e a concordata não poderiam contradizer a Constituição, especialmente o art. 19, inciso I, que veda a todas as instâncias do Estado estabelecer ou subvencionar cultos religiosos ou manter com eles relações de dependência ou aliança. A ressalva seria a colaboração, na forma da lei, em matéria de interesse público.

Justamente o contrário disso acontece nos sistemas públicos de ensino, ${ }^{5}$ onde prevalece o proselitismo religioso, confessional ou interconfessional. E o agravante é que esse proselitismo é dirigido às crianças e aos adolescentes. Com efeito, eles são mais suscetíveis à pressão social e psicológica proveniente das autoridades escolares e mesmo de seus colegas, de modo que preferem acompanhar a prática do que entendem ser "normal" para evitar o estigma. A previsão constitucional e legal de que 
o Ensino Religioso seja facultativo não muda essa situação, pois acarreta um grande sacrifício aos pais e aos próprios alunos que se dispõem a se valer desse direito. ${ }^{6}$

Já que a Constituição determina que as escolas públicas ministrem o Ensino Religioso durante o horário das aulas, a ADI pede que a LDB e a concordata sejam harmonizadas com ela, de acordo com o princípios jurídicos da unidade e da harmonia. Como a Constituição está acima da LDB e da concordata, seus textos devem ser reinterpretados de modo a vedar àquela disciplina conteúdos confessionais ou interconfessionais. No lugar deles, a disciplina deveria contemplar a exposição e a discussão, sem qualquer proselitismo, das doutrinas, das práticas, da história e de dimensões sociais das diferentes religiões, bem como de posições não religiosas, como o agnosticismo e o ateísmo, sem qualquer tomada de partido por parte dos educadores. Estes, por sua vez, deveriam ser professores da rede pública de ensino, admitidos por critérios que não incluíssem o credenciamento das instituições religiosas. Assim procedendo, as escolas públicas propiciariam a opção dos alunos para fazer suas próprias escolhas, dentro do objetivo maior de formar pessoas dotadas de capacidade de reflexão crítica.

Na hipótese de não ser possível interpretar a concordata de modo a sintonizá-la com a Constituição brasileira, a ADI solicitou que fosse considerado inconstitucional parte do artigo 11 desse acordo, justamente o que especificou o "Ensino Religioso católico e de outras confissões religiosas". A ação foi acolhida pelo STF, recebeu o n. 4.439 e foi distribuída para relato.

Tenha ou não sucesso a ADI, ela mostra que a demanda de laicidade se espraia da sociedade para o Estado.

\section{Folia pedagógica}

Ensino Religioso nas escolas públicas - por que não? A julgar pela resposta que seus defensores dão, os alunos só teriam a ganhar. Como todas as religiões são boas, já que Deus é o mesmo, tal disciplina propiciaria tolerância dos alunos uns com os outros, formando uma disposição favorável à solidariedade fora da escola; respeito às autoridades escolares, induzindo sentimento análogo no âmbito da sociedade política. Pura idealização! No mundo real, há crenças dominantes e dominadas, que dividem os alunos ao invés de os unir. Os filhos de não crentes são discriminados até mais que os dos adeptos de religiões minoritárias. Não bastasse isso, a religião ocupa recursos humanos e materiais que fazem falta à escola pública. E enseja a disputa de corações e mentes infantojuvenis para a verdade provinda dos argumentos de autoridade que não é deste mundo, portanto transcendentes, ao passo que a escola pública precisa estar ancorada justamente na ciência deste mundo, ou seja, imanente. A importância dessa distinção é bem sabida pelos professores de Biologia ao tratarem da evolução das espécies! 
Ao contrário do que acontece nas grandes democracias representativas, a religião parece tão natural, nas escolas públicas do Brasil, que muita gente - inclusive gente estudada, especialista em Educação - nem presta atenção nela. Uma simples visita pode mostrar a presença generalizada da religião: os nomes das escolas, nichos com imagens de santos, crucifixos, cartazes com trechos bíblicos, orações no início das reuniões dos professores, antes das aulas e da merenda. Presença religiosa cristã, bem entendido. Apesar da liberdade de crença determinada pela Constituição, valor democrático compartilhado por grande parte da população brasileira, os adeptos das religiões afro-brasileiras e de religiões minoritárias, os agnósticos e os ateus parecem aos professores e alunos filiados aos credos dominantes como seres exóticos, frequentemente alvo de chacotas e de estigmas violentos.

Não é exagero dizer que, nas escolas públicas brasileiras, a religião entra pela porta dos fundos, aberta pelas direções ou por elas tolerada em nome da aliança com docentes e funcionários. A religião entra, também, pela porta da frente das escolas públicas, na forma da disciplina Ensino Religioso. Embora seja dita facultativa, na prática ela é frequentemente obrigatória para os alunos.

As respostas de 55 mil diretores de escola pública de Ensino Fundamental aos questionários de 2011 da Prova Brasil dão uma ideia aproximada da situação. ${ }^{7}$ A presença da religião no dia a dia das escolas públicas foi admitida por mais da metade dos diretores: 51\% deles disseram que em suas escolas "há costume de se fazer oração ou cantar músicas religiosas (na entrada, antes do lanche, etc.)". A maioria dos diretores (66\%) disse que suas escolas oferecem o Ensino Religioso, sendo que praticamente a metade destes reconhece que obriga os alunos a frequentá-las (49\%), em flagrante transgressão da Constituição e da LDB. Um dado preocupante para os interessados na prática da liberdade de opção na escola pública é a resposta à pergunta sobre a existência de "atividades alternativas para os estudantes que não queiram participar das aulas de Ensino Religioso". A maioria dos que as oferecem (79\%) respondeu negativamente. Disciplina reconhecida facultatória pelos diretores das escolas públicas?

O que acontece nas aulas de Ensino Religioso provém de um cardápio variado. Umas turmas recebem aula de uma dada religião, outras de uma espécie de denominador comum às religiões da tradição cristã (católica e evangélicas), fruto de correlações de força onde nenhuma delas consegue a hegemonia na disputa tão real quanto dissimulada; outras, ainda, recebem aulas sobre "valores", que negam sua genealogia religiosa, mas não passam de expressões confessionais de regras de conduta conservadoras ou reacionárias - uma espécie devota de Educação Moral e Cívica, de triste memória. Relações sexuais fora do casamento, homossexualismo, aborto e drogas são temas frequentes nessas aulas. Isso, apesar de os temas transversais dos Parâmetros Curriculares Nacionais para o Ensino Fundamental terem um tratamento laico. 
Concentremos nossa atenção nas relevantes conclusões da pesquisa empírica conduzida pela professora da Faculdade de Educação da UFRJ Ana Maria Cavaliere nas escolas de Ensino Fundamental da rede estadual do Rio de Janeiro, divulgadas em dois artigos publicados em 2006 e 2007. Ela resumiu numa palavra o que encontrou: a escola pública foi colonizada pela religião. Acompanhemos seu raciocínio.

Os professores, os dirigentes educacionais e os políticos, de um modo geral, estão de acordo sobre o que acreditam ser uma ameaça de descontrole social existente nos bairros populares, ameaça essa que estaria, também, dentro das escolas públicas, na forma de comportamentos indesejados, de agressividade e de resistência dos alunos à escola. A religião seria a "solução" encontrada pelo Estado e pelo magistério. O Estado abdica de sua função socializadora e cede às instituições religiosas parte de suas responsabilidades. O magistério, por sua vez, sobrecarregado de trabalho, não consegue dar conta das atividades correntes da escola nem promover atividades artísticas, culturais, esportivas, comunitárias ou de lazer que sejam capazes de enriquecer o ambiente escolar e as vidas das crianças que o frequentam e as de suas famílias. As bibliotecas e salas de leitura, quando existem, têm acesso restrito. Tampouco há atividades de apoio aos estudantes, que contem com a intervenção de psicólogos, assistentes sociais ou profissionais da saúde. Ou seja, há um vazio curricular e extracurricular na escola, que é preenchido pela religião. Mesmo existindo um sentimento de que a escola deva ser laica, o professorado capitula e acaba aceitando a oferta que vem de fora. Na prática, as aulas de religião são justificadas pelos professores como uma ferramenta a mais na luta pelo fortalecimento do controle dos alunos e pela consequente preservação de sua autoridade. A percepção generalizada de que há uma predisposição, entre muitas famílias de alunos, de adesão a um credo religioso faz com que esse caminho pareça útil, inclusive para professores e diretores que não estão pessoalmente envolvidos na prática de alguma religião.

O professor de Ensino Religioso passa a ocupar, então, o lugar de auxiliar da direção da escola nas atividades de orientação educacional, nos projetos coletivos, nas atividades culturais e comemorativas. Em certos casos, esse professor adquire um importantíssimo papel na definição e na execução da proposta pedagógica da escola. Assim é que o Ensino Religioso acaba colonizando áreas da vida escolar relativas à formação geral e à orientação educacional.

Em suma, a presença forte da religião na escola é sintoma de sua crise de identidade e de eficácia. O fortalecimento da presença da religião na escola pública vem na exata medida em que a ação educativa escolar se enfraquece. Revela, de um lado, a capitulação do Estado e, de outro, o fracasso do sistema educacional a uma ação mais efetiva no processo de socialização e de incorporação social das grandes massas da população (CAVALIERE, 2006, 2007).

Bizarrice fluminense ou amostra expressiva do ensino público brasileiro? 


\section{Conclusão}

A partir da observação da presença da religião, particularmente do Ensino Religioso, nas escolas públicas, a conclusão que podemos tirar é de que os grupos religiosos de pressão, especialmente o clero católico, conseguiram fazer valer a determinação constitucional sobre a única disciplina escolar mencionada na Carta Magna. A partir daí, prosseguiram na pressão para deixar a legislação infraconstitucional cheia de claros, de modo a poderem completá-la, conforme seus interesses proselitistas, ostensivos ou dissimulados, nas instâncias inferiores do Estado - nos Conselhos Nacional e Estaduais de Educação, nas Assembleias Legislativas e nas Câmaras de Vereadores, bem como nas instâncias correspondentes do Poder Executivo. Numa palavra: no que diz respeito à presença da religião na escola pública, o regime federativo foi de grande valia para a geração da anomia jurídica, propiciadora, por sua vez, da folia pedagógica.

Inverter esse quadro, só mesmo com intervenções que compensem tal efeito: reforma da Constituição, suprimindo-se o Ensino Religioso nas escolas públicas como apêndice curricular, seguida de reforma correspondente da LDB. O CNE precisa deixar de rodeios e ambiguidades, para emitir logo parecer/resolução dizendo, pelo menos, o que não pode ser feito em nome do Ensino Religioso. Se lhe falta disposição, mirem-se os conselheiros da Câmara de Educação Básica no Parecer n. 4/2011, do Conselho Municipal de Educação do Rio de Janeiro, que teve a lucidez e a coragem de afirmar que "o Ensino Religioso não constitui uma área de conhecimento específica que deva ser tratada nos moldes disciplinares". Além de reconhecer o caráter laico da escola pública, o parecer relatado por Rita Ribes recomendou que se aguardasse a manifestação do STF sobre a ADI n. 4.439. Mesmo atropelada pelo prefeito, a manifestação do conselho carioca é um marco na segunda onda laica.

E os valores? Têm razão os que chamam a atenção para a existência de um vazio ético no ensino público. Mas, ao contrário do que se pretende, a religião não é conteúdo adequado a preenchê-lo. A ética laica é o que faz falta, como, aliás, apontam, implicitamente, os temas transversais dos Parâmetros Curriculares Nacionais do Ensino Fundamental, de 1997, e a Resolução CNE/CP n. 1/2012 do Conselho Nacional de Educação, sobre as Diretrizes Nacionais para a Educação em Direitos Humanos. ${ }^{8}$ Num texto tão oportuno quanto correto, o Conselho Pleno daquele órgão colegiado elencou os sete princípios fundamentais da Educação em Direitos Humanos, não só em termos laicos, como, também, explicitando a laicidade do Estado como um deles. Os outros seis são os seguintes: dignidade humana; igualdade de direitos; reconhecimento e valorização das diferenças e diversidades; democracia na educação; transversalidade, vivência e globalidade; e sustentabilidade socioambiental. A não ser o 
primeiro, nenhum desses princípios pode ser creditado a religião alguma. A dignidade humana, sim, teve, na sua gênese histórica, protagonismo seminal do cristianismo, que, todavia, veio a contribuir fortemente para o seu contrário, mediante o apoio e a prática da escravidão, da dominação sexual e de gênero, da sujeição de povos e de religiões concorrentes, sem falar na repressão aos dissidentes internos. E não são favas contadas! Não há como desconhecer que a dignidade humana é, na atualidade, valor assumido e potencializado por outras correntes de pensamento e ação, inclusive antirreligiosas, como as libertárias, por exemplo. Pretender que a dignidade humana seja um valor propriamente religioso é uma redução teórico-prática que a educação pública não pode tolerar.

A criação do Sistema Nacional de Educação tem sido justificada por diversos elementos, entre os quais não aparece a laicidade da educação pública. No meu entender, tal omissão expressa a insuficiente compreensão do Estado republicano e de suas políticas, em especial as políticas educacionais. Esse conveniente (conivente?) silêncio propicia a situação atual do Ensino Religioso nas escolas públicas, marcada pela anomia jurídica e pela folia pedagógica. Ambas prosperam na fragmentação do aparato educacional brasileiro em múltiplos sistemas, o que abre caminho para a luta pela hegemonia religiosa no campo educacional, privando a escola pública de um elemento essencial da prática republicana - a liberdade de pensamento e de crença, decorrente da laicidade.

Na perspectiva aqui traçada, a constituição do Sistema Nacional de Educação poderá ensejar a retomada dessa questão crucial, na linha da autonomização do campo educacional defendida (sem este nome) em pronunciamentos marcantes dos educadores brasileiros, a exemplo do Manifesto dos Pioneiros da Educação Nova (IV CNE, 1932) e da Carta de Goiânia (IV CBE, 1986) - ambos reivindicaram a laicidade na escola pública. Para que tudo isso ocorra, é preciso superar o tradicional oportunismo de adular os cleros e a habitual covardia diante de sua já conhecida chantagem: "querem tirar Deus da escola pública!".

\section{Notas}

1. Levantamento realizado pela ONG Ação Educativa calculou em um quarto a fração do número dos projetos de lei sobre temas educacionais em tramitação na Câmara dos Deputados e no Senado, que propunham a criação de novas disciplinas ou a mudança nos conteúdos do currículo escolar. O número desses projetos de lei chegava a 250, em estudo finalizado em novembro de 2010.

2. No texto final da LDB, o Ensino Religioso não é mencionado no artigo 26, que trata dos currículos dos ensinos fundamental e médio. Vão mencionados a Língua Portuguesa; a Matemática; o conhecimento do mundo físico e natural e da realidade social e política, especialmente do Brasil; a Arte; e a Educação Física. Não vale a argumentação de que é mencionado apenas o que é comum aos dois níveis de ensino, pois o parágrafo $5^{\circ}$ desse artigo determina que, a partir da $5^{a}$ série, seja incluída pelo menos uma língua estrangeira moderna. 
3. A confusão fica agravada ao atentarmos para trecho do parecer CNE/CEB n. 4/98, que chamou a atenção para que se evitassem propostas pedagógicas reducionistas ou excludentes, que levassem a excessos, como, entre outras, as de "grupos religiosos apenas para si". Por suposto, o interconfessionalismo previsto na reforma do artigo 33 da LDB estaria isento das preocupações da relatora.

4. A ADI teve início com representação movida pelo procurador regional do Rio de Janeiro, Daniel Sarmento, e foi endossada pela procuradora-geral em exercício, Deborah Duprat, em 30 de junho de 2010 .

5. Estou ciente da impropriedade desta expressão, aqui empregada apenas para facilitar a comunicação. Para a crítica dessa impropriedade, ver Saviani (2010).

6. O caráter facultativo do Ensino Religioso esbarra nas barreiras da burocracia e da distância cultural e social entre os pais de alunos e as direções escolares. Se, ao invés de os pais terem de pedir dispensa dessa disciplina, a prática fosse a oposta (isto é, os interessados é que deveriam tomar a iniciativa de solicitá-la), é de se esperar que as turmas fossem bem menores. A prática não muda justamente para se manter a imposição dissimulada.

7. As questões de número 206 a 212 versaram sobre o Ensino Religioso. Os dados aqui citados foram acessados em 18/12/2012 no endereço: <www.qedu.org.br/brasil/panorama/diretor>.

8. Essa resolução foi baseada no parecer CNE-CP n. 8/2012, relatado por Rita Gomes do Nascimento, em comissão formada por Antônio Carlos Caruso Ronca, Raimundo Moacir Feitosa e Reynaldo Fernandes.

\section{Referências}

BATISTA, C.; MAIA, M. (Org.). Estado laico e liberdades democráticas. Recife: Articulação das Mulheres Brasileiras; Rede Nacional Feminista de Saúde; SOS Corpo-Instituto Feminista para a Democracia, 2006.

CAVALIERE, A.M. Quando o Estado pede socorro à religião. Revista Contemporânea de Educação, Rio de Janeiro, n. 2, p. 5, 2006.

CAVALIERE, A.M. O mal-estar do ensino religioso nas escolas públicas. Cadernos de Pesquisa, São Paulo, n. 131, maio/agosto 2007.

CUNHA, L.A. Educação, Estado e democracia no Brasil. São Paulo: Cortez, 1991.

CUNHA, L.A. A educação na concordata Brasil-Vaticano. Educação \& Sociedade, Campinas, v. 30, n. 106, p. 263-280, jan./abr. 2009a.

CUNHA, L.A. A luta pela ética no ensino fundamental: religiosa ou laica? Cadernos de Pesquisa, São Paulo, n. 137, maio/ago. 2009b.

CUNHA, L.A. A educação carente de autonomia: regime federativo a serviço da religião. Retratos da Escola, Brasília, DF, v. 6, n. 10, p. 55-104, jan./jun. 2012.

CUNHA, L.A.; CAVALIERE, A.M. O Ensino Religioso nas escolas públicas brasileiras: formação de modelos hegemônicos. In: PAIXÃO, L.P.; ZAGO, N. (Org.). Sociologia da Educação: pesquisa e realidade brasileira. Petrópolis: Vozes, 2007. 
CURY, C.R.J. Ensino Religioso na escola pública: o retorno de uma polêmica recorrente. Revista Brasileira de Educação, Campinas, v. 27, p. 183-191, set./dez. 2004.

DINIZ, D.; LIONÇO, T.; CARRIÃO, V. Laicidade e Ensino Religioso no Brasil. Brasília, DF: Unesco; Letras Livres, 2010.

DUARTE, L.F.D.; GOMES, E.C.; MENEZES, R.A.; NATIVIDADE, M. (Org.). Valores religiosos e legislação no Brasil: a tramitação de projetos de lei sobre temas morais controversos. Rio de Janeiro: Garamond, 2009.

FISCHMANN, R. Estado laico. São Paulo: Memorial da América Latina, 2008a.

FISCHMANN, R. (Org.). Ensino Religioso nas escolas públicas: impactos sobre o Estado laico. São Paulo: Fafe; Feusp; Prosare, 2008b.

FISCHMANN, R. (Org.). Ensino Religioso em escolas públicas: ameaças ao Estado laico. Notandum, São Paulo, n. 28, jan./abr. 2012. Disponível em: <http://www.hottopos.com/notand28/>.

INSTITUTO BRASILEIRO DE GEOGRAFIA E ESTATISTICA (IBGE). Censos demográficos de 1960, 1980, 2000 e 2010. (Tabulações avançadas).

LOREA, R.A. (Org.). Em defesa das liberdades laicas. Porto Alegre: Livraria do Advogado, 2008.

MARTEL, L.C.V. Laico, mas nem tanto: cinco tópicos sobre liberdade religiosa e laicidade estatal na legislação constitucional brasileira. Revista Jurídica, Brasília, DF, n. 86, ago./out. 2007.

PIERUCCI, A.F. Bye-bye Brasil: o declínio das religiões tradicionais no Censo 2000. Estudos Avançados, São Paulo, v. 18, n. 52, p. 17-28, 2004.

RANQUETAT JUNIOR., C.A. Laicidade, laicismo e secularização: definindo e esclarecendo conceitos. Revista Tempo da Ciência, Santa Maria, v. 15, n. 30, p. 59-72, 2008.

SAVIANI, D. Organização da educação nacional: Sistema e Conselho Nacional de Educação, Plano e Fórum Nacional de Educação. Educação \& Sociedade, Campinas, v.31, n. 112, p. 769-787, jul./set. 2010.

Recebido em 9 de junho de 2013.

Aprovado em 17 de julho de 2013. 